\title{
Voluntary Delisting In Korea: Causes And Impact On Company Performance
}

\author{
Sun Min Kang, Ph.D., Chung-Ang University, South Korea
}

\begin{abstract}
This research investigates the attributes of firms that choose to voluntarily delist in Korea, including the evolution of firms after delisting, using performance indicators such as total assets, revenue, and net income. Empirical evidence suggests that the higher the shareholding ratio of the largest shareholder and the higher the growth prospects and liquidity, the greater the incentive for voluntary delisting. In addition, firms in non-high-tech industries choose to delist more often than those in high-tech industries. Further, firms that have delisted show lower total assets, revenues, and net incomes than listed firms, and these gaps increase over time.
\end{abstract}

Keywords: Voluntary Delisting; The Largest Shareholder Ratio; Growth Prospect; Performance

\section{INTRODUCTION}

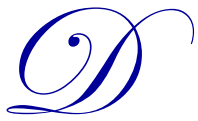

elisting refers to the loss of the trading eligibility of a listed company's marketable securities and the cancellation of a qualified listing. Generally, delisting happens under the authority of a stock exchange. When a serious management problem occurs (e.g., bankruptcy) and investors incur losses, or when there is a risk of undermining the order of the stock market, the stock exchange will delist a company that meets the delisting criteria in order to protect investors, unless the reason for delisting is resolved during a certain grace period. Alternatively, a company may voluntarily delist itself through the public purchase of treasury stock.

Many unlisted companies undertake an initial public offering (IPO) to obtain funding without debt by issuing shares, despite the complicated conditions and procedures of IPOs. Although IPOs are convenient for capital financing, one major disadvantage is that shares become dispersed. As a company owned solely by the largest stockholder comes to be owned jointly by general stockholders, the company's management process may become more difficult. Consequently, a company that has grown beyond a certain level after listing will often want to delist voluntarily to enhance management efficiency.

Additionally, a company with a foreign investor as its largest stockholder may delist itself to resume listing in another overseas stock market where it can be valued properly. According to the Korea Exchange, for example, between December 2011 and December 2014, the stock market rose by 105\% in Japan and 33.6\% in China, while the increase was only $5.3 \%$ in South Korea; thus, long-lasting stock market recession is the main reason that foreign funds have left the Korean stock market.

To protect investors, securities regulations generally prevent entrepreneurial ventures from entering the stock market (Carpentier and Suret, 2010). Accordingly, listing a company can be a time- and resource-intensive process. Delisting can be just as demanding, especially voluntarily delisting, because a company's largest shareholder and senior management cannot simply choose to delist at will. The largest shareholder must first purchase a majority of the shares through a tender offer. Because the tender offer price is usually set at a premium compared with the market's stock price, delisting is thus expensive. ${ }^{1}$ Nonetheless, firms do sometimes choose to voluntarily delist.

Some firms decide to delist within three to five years of listing. One company even delisted after a single year. ${ }^{2}$ Recent press reports suggest that an increasing number of firms delist because of decision-making difficulties caused by shareholder influence, which outweigh the benefits of being a public company (e.g., ease of financing and enhancement of corporate credit). For example, Dell Inc. delisted in 2013 and regained its entrepreneurial spirit. After the company went private, the board consisted of only three members, including the founder, Michael Dell, which 
made it easier for the board to make critical business decisions. ${ }^{3}$ Although the outcome of Dell's privatization remains to be seen, the firm chose to delist to prevent shareholder interventions.

Undervaluation is the most commonly stated reason for voluntary delisting. With stock prices continuously falling because of the economic recession, many managers believe that the stock market has lost its role as a platform for financing. If a stock market values a firm incorrectly, the firm has no reason to remain listed and continue to pay large maintenance fees. Consequently, many firms choose to go private.

This study examines the characteristics of companies that voluntarily delist to verify whether the reasons given by the press and companies for voluntary delisting are reasonable given that companies must give up the many advantages of listing and absorb delisting costs. Additionally, this study verifies whether companies that voluntarily delist achieve their intended outcomes from delisting. For this purpose, the business performance of voluntarily delisted firms after their delisting is examined.

Comparisons of performance indicators such as total assets, sales, and net profits between firms that voluntarily delisted and those that remained listed reveal that the performance of delisting companies worsened after delisting. This finding may indicate that companies that have voluntarily delisted should reconsider whether they have achieved their goals by delisting. These results provide useful information for companies considering voluntarily delisting as well as for their interested parties.

\section{VOLUNTARY DELISTING REGULATIONS AND STATUS}

\section{Voluntary Delisting Regulations}

Firms gain numerous benefits by going public, including easier financing, increased investor awareness, and improved financial transparency. For example, firms are able to raise capital through the issuance of new shares, thereby increasing their liquidity. Firms that are not public must raise capital through their small pool of shareholders or through a bank. Public firms, however, can raise capital from a wider pool of investors, which also increases shareholder involvement. Additionally, public firms can gain tax advantages over private firms, such as exemption from share transfer income tax and dividend income tax. Going public also provides public relations benefits and enhanced public confidence, both of which can boost brand image and operating performance.

Nonetheless, since 1996, the number of voluntarily delisted firms has increased, even though voluntary delisting is a lengthy process involving numerous stakeholders, including regulators, shareholders, creditors, management, and employees. It is important for a firm to consider the circumstances of these various stakeholders and ensure that they do not incur economic losses due to voluntary delisting. To minimize such losses, policymakers regulate the delisting process and review whether the necessary procedures havebeen followed before approving delisting applications. Delisting is a time-consuming process (Morgenstern et al., 2004) because a firm must reach an agreement with each of its stakeholders and comply with the applicable regulations. It is therefore important to examine the regulations governing voluntary delisting.

The Korea Exchange acts as the sole securities exchange operator for stocks and derivatives in Korea. As the overseer of capital markets, the Korea Exchange maintains fairness and stability by establishing rules and detailed enforcement regulations for listing, announcements, and delisting. It also protects investor interests and ensures stock market transparency. Accordingly, firms that voluntarily delist must be reviewed by the listing committee in accordance with the applicable regulations (KOSPI Market Listing Regulation, 2014; KOSDAQ Market Listing Regulation, 2014).

First, the largest shareholder of the firm must purchase any outstanding shares (including foreign shares and depositary receipts of foreign shares) through a tender offer. This largest shareholder announces to the public that it will purchase the shares at a specified time and price. These requirements protect minority shareholders during the voluntary delisting process. However, as tender offers are usually made at a premium compared with the market's stock price, delisting can become expensive. For example, when mobile phone camera component manufacturer Cowell Ltd delisted in 2009, it purchased shares through a tender offer of KRW 4,300 per share, which amounted to a $25 \%$ premium over the market price of KRW 3,510. Indeed, delisting can be just as time- and resource-intensive as listing. 
Second, firms delisting from the Korea Composite Stock Price Index (KOSPI) Exchange must demonstrate that 95\% of their common shares are owned by the largest shareholder on the day of the delisting application. In other words, a company cannot apply for delisting if the largest shareholder has less than $95 \%$ of shareholder equity. By contrast, on the Korean Securities Dealers Automated Quotations (KOSDAQ) Exchange, there are no clear guidelines for the largest shareholder's ownership percentage when delisting; however, the minority shareholder protection procedures are similar to those of the KOSPI Exchange. If minority shareholders oppose a delisting, delisting costs will increase, or the delisting will be withdrawn altogether. For example, Citibank, the largest shareholder of Citibank Korea, began acquiring the shares of minority shareholders in June 2004. It postponed the delisting process for a year, though, because it was unable to acquire the remaining 260,000 shares by April 2005.

Third, the largest shareholder must promise investors who have not accepted the tender offer that they will be given an opportunity to sell their shares within a certain period after delisting. The largest shareholder must also ensure that the other conditions of the tender offer are consistent with public interest and investor protection requirements, which usually means that minority shareholders who wish to sell their shares after delisting (usually within a period of six months) must be permitted to sell them to the largest shareholder at the tender offer price. These rules protect minority shareholders and ensure that firms fulfill their responsibilities, even after delisting. As the aforementioned regulations suggest, delisting can occur only after strict criteria are met; consequently, the largest shareholder and senior management cannot act unilaterally, and delisting can be as time- and resource-intensive as going public.

\section{Voluntary Delisting Status}

Between 1996 and 2012, 49 firms voluntarily delisted from the KOSPI and KOSDAQ Exchanges. Voluntary delisting continued until 2005 and then stopped for three years between 2006 and 2008. It then became active again in 2009. Voluntary delisting has occurred frequently during three periods: (1) right after the Asian financial crisis, when nine firms delisted in 1998 (18.37\%) and six firms delisted in 1999 (12.24\%); (2) in 2004 and 2005, when six firms $(12.24 \%)$ and seven firms (14.29\%), respectively, voluntarily delisted; and (3) in 2012, when five firms voluntarily delisted (10.20\%).

Of the 49 firms that voluntarily delisted between 1996 and 2012, seven (14.28\%) were financial institutions and 42 $(85.72 \%)$ were nonfinancial institutions. Of the 14 firms that voluntarily delisted from the KOSPI Exchange, four were financial institutions and 10 were nonfinancial institutions. Of the 35 firms that voluntarily delisted from the KOSDAQ Exchange, three were financial institutions, and 32 were nonfinancial institutions. Thus, $71.43 \%$ of voluntarily delisted firms were from the KOSDAQ Exchange, suggesting that KOSPI-listed firms, which tend to be larger and more financially stable, are more cautious about their decisions to voluntarily delist.

17 (35\%) firms of the 49 firms were delisted within three years of going public, all of which had been listed on the KOSDAQ. Of the 32 nonfinancial KOSDAQ firms, 70\% (22 firms) delisted within five years of going public. The process of listing and delisting within a short timeframe is costly, not only for the company, but for society. By contrast, $71 \%$ (10) of the 14 firms that delisted from the KOSPI Exchange had been public for longer than 10 years. ${ }^{4}$

\section{LITERATURE REVIEW AND HYPOTHESIS DEVELOPMENT}

\section{Literature on Delisted Firms}

The literature on voluntary delisting can be classified into three main periods. The literature of the 1980s focused on the effects of voluntary delisting on shareholder wealth and profits. In the 1990s, the literature mainly analyzed the financial attributes of voluntarily delisting firms. Then, in 2002, after the adoption of the Sarbanes-Oxley Act (SOX) in the United States, the costs of being listed significantly increased, and the literature began to focus on the specific reasons behind the steep increase in the number of voluntarily delisting firms (United States House of Representatives, 2002).

DeAngelo et al. (1984) analyzed 72 firms that voluntarily delisted between 1973 and 1980 to assess the effect of delisting on shareholder wealth. Their results showed that voluntary delisting ultimately increased company profitability by reducing maintenance costs and enabling management to make faster business decisions. However, 
DeAngelo et al. (1984) also suggested that voluntary delisting treated minority shareholders unfairly by forcing them out of the investor pool. Lehn and Poulsen (1989) argued that voluntary delisting resolves the free cash flow agency problem and that firms with a high level of undistributed cash flow are more likely to go private. This phenomenon is more prevalent in firms in which management possesses a low share of equity.

Rao et al. (1995) analyzed 118 firms that voluntarily delisted between 1984 and 1988 to determine their common attributes. They suggested that if earnings attributable to shareholders are in the form of potential cash, such as market value or growth potential, firms will likely maintain their listed status. However, if earnings attributable to shareholders are closer to actual cash, such as dividends, firms will likely go private. Halpern et al. (1999) analyzed 126 firms that voluntarily delisted between 1981 and 1985 by separating them into two categories based on whether the management equity share was high or low, determining whether there were any differences in the leveraged buyout (LBO) method. The results revealed a significant difference between the two groups in terms of the LBO motive and transaction method. Where management had a high (low) equity share, leverage exceeded (were below) debt capabilities.

During 2001 and 2002, major corporate accounting scandals (e.g., Enron, WorldCom, and Tyco) had a significant effect on investor confidence in financial reporting integrity. Congress passed SOX on July 25, 2002 to help restore public trust (Chang et al., 2012). The number of voluntarily delisting firms has increased since SOX, and various studies have tried to determine the reason. Morgenstern et al. (2004) analyzed post-SOX voluntary delisting from a theoretical perspective. Their research showed that the number of firms voluntarily delisting from the US stock exchange increased by $30 \%$ during the 16-month periods before and after SOX, primarily among firms with undervalued share prices relative to firm value.

Marosi and Massoud (2007) found that firms with fewer valuable growth opportunities, greater insider ownership, and lower market momentum were more likely to go private. Moreover, they determined that an increase in audit fees due to SOX was the key trigger for the increase in voluntary delisting. Leuz et al. (2008) found that, after SOX, many firms went private due to agency problems, distress, and increased compliance costs. However, their findings suggested that insider interests also influence the decision to go private, and at least for some firms, cost savings are not the only consideration. For example, firms with weaker governance and outside monitoring, larger accruals, and larger free cash flows are more likely to go private.

In the UK institutional setting, Pour and Lasfer (2013) investigated the determinants and consequences of voluntary delisting. They focused on the effects of leverage on the delisting decision and showed that firms unable to raise additional equity capital were more likely to opt for voluntary delisting. However, they had insufficient data to determine what happened to those firms after they went private.

The literature on delisting in Korea is limited to studies of compulsory delisting. The regulations imposed by financial authorities are crucial for maintaining the integrity of the capital market (Hwang et al., 2014). The Korea Exchange implemented a substantial review system for delisting from the KOSDAQ Exchange in February 2009 and strengthened its delisting policy. Park and Jee (2010) argued that the introduction of this review system significantly reduced earnings management by listed firms, thereby increasing the transparency of accounting information and restoring market confidence. KOSDAQ Listed Companies Association (2010) adopted a different approach and analyzed the insolvency patterns of compulsorily delisted firms using financial ratios. Additionally, Hwang et al. (2014) verified that nonfinancial information can be a good leading indicator for delisting. They argued that a delisting model using nonfinancial information is meaningful because it can provide diverse stakeholders with early warning signals that predict.

The media have mentioned various reasons for delisting. Some firms voluntarily delist to prevent intervention by minority shareholders and financial authorities, to increase dividends, and to maximize parent-company earnings. Other firms have been known to hand over major shareholdings and then announce tender offers to accelerate the managerial decision-making process. Additionally, several firms have chosen to delist because of undervaluation in the stock market and the resulting difficulties in raising capital through public offerings. This research empirically analyzes the attributes of voluntarily delisting firms and investigates how such firms have changed since going private. 


\section{Hypothesis Development}

The most commonly mentioned reason for voluntary delisting is the undervaluation of shares. If management believes that the true value of a company exceeds the market value, they may decide to delist voluntarily. Marois and Massoud (2007) argue that a company's potential growth options can be measured by q-ratio. They claim that there are two options that a company with a high q-ratio can take. First, it may wish to stay public to raise further financing in the market for obtaining additional business opportunities in the future. Another option is that a company may wish to take it private in order to enjoy the implied growth options resulted from a high q-ratio.

In the Korean stock market, however, firms might not voluntarily delist to improve their value. According to the Financial Supervisory Service, Kyung Nam Energy Co., Ltd began the process of delisting through the public purchase of treasury stocks in 2014 and resumed the process in 2015. Kyung Nam Energy Co., Ltd embarked on the public purchase of treasury stocks of 15.4 million shares in February 2014, but only 8.0 million shares $(51.80 \%)$ responded to the purchase, so the company was unable to meet the requirement of purchasing $95 \%$ of the total stocks it had issued, and it thus failed to delist. Additionally, Busan City Gas Co. Ltd proceeded with a public purchase for delisting at the end of 2013 despite its previous failure to delist. Daesung Energy Co. Ltd also considered voluntarily delisting in 2004. In November 2012, Ko-won Energy Service Co., Ltd voluntarily left the stock market after a public purchase. These companies, which run their businesses based on franchises, have explained that the cost of listing (including delays in management decision-making and obligation to make public announcements) was the reason that they applied for delisting, rather than merely an effect of listing.

High-growth firms go private so that their largest shareholders can take advantage of good performance. Thus, this study proposes the following hypothesis.

Hypothesis 1: Firms with higher growth prospects are more likely to delist voluntarily.

Listed firms have numerous stakeholders including regulatory authorities, shareholders, creditors, management, and employees. To delist voluntarily, firms must reach an agreement with these various stakeholders, particularly with minority stakeholders who tend to have no voice during the voluntary delisting process. Voluntarily delisting firms resolve any conflicts of interest with minority shareholders through tender offers. Therefore, if the largest shareholder ratio is already high, fewer shares must be acquired, resulting in a lower financial burden during the voluntary delisting process.

Moreover, if the shareholding ratio of the largest shareholder is already high, raising capital externally through a public offering becomes less meaningful. Maintaining a listed status also becomes redundant, because few shares are being traded in the markets, resulting in inefficient price formation. If outstanding shares do not meet certain monthly trade volume requirements, firms could be forced to delist. In the KOSPI Exchange, compulsory delisting occurs if the average monthly trading volume of a firm for two consecutive six-month periods is less than $1 \%$ of the outstanding shares. In the KOSDAQ Exchange, compulsory delisting occurs when the average monthly trading volume for two consecutive three-month periods is less than $1 \%$ of the outstanding shares. Consequently, if the shareholding ratio of the largest shareholder is too high, a firm could be compulsorily delisted because of low share-trading activity. In this context, firms might delist voluntarily to prevent compulsory delisting. Accordingly, this research proposes the following hypothesis.

Hypothesis 2: Firms with a high largest shareholder ratio are more likely to voluntarily delist than firms with a low largest shareholder ratio.

The growth of a company has a positive relationship with liquidity. Firms with high growth prospects tend to have higher liquidity and better cash flow (Kim and Cho, 1996). If a company with large cash reserves and high liquidity is undervalued in the stock market, it is likely to use internal cash reserves rather than obtain financing through the stock market. Because of the maintenance fees required to remain listed, it may be better for such a company to delist. Accordingly, firms with high liquidity are more likely to voluntarily delist than those with low liquidity. 
This situation can be considered from another perspective. For a company to delist voluntarily, the largest shareholder must acquire the outstanding shares, typically at a premium. In this context, Jeong and Ha (2006) found that a tender offer results in a positive excess return. In other words, a firm seeking to delist voluntarily must have sufficient capital and liquidity to pay more than the market price to acquire shares through a tender offer. ${ }^{5}$ Such a firm must have sufficient current assets for a rapid conversion into cash. With this in mind, Lehn and Poulsen (1989) analyzed 263 voluntarily delisted firms between 1980 and 1989 and showed a positive relationship between free cash flow and voluntary delisting. In other words, without sufficient liquidity, firms are unable to easily decide whether to go private. Thus, regardless of one's perspective, voluntary delisting requires cash and liquidity. Accordingly, the following hypothesis is proposed.

Hypothesis 3. Liquid firms are more likely than other firms to delist voluntarily.

The most representative major industries in South Korea are high-tech industries such as electronics and chemistry. ${ }^{6}$ The number of continuously listed companies in high-tech industries is about 1.4 times the number of those in other industries. Companies included in the representative major industries in South Korea are preferred by investors, and it is very likely that their stock prices have been formed fairly. Thus, it is easier for companies in high-tech industries to increase and finance capital than for companies in non-high-tech industries. Therefore, it can be assumed that industries with a high capital demand, such as electronics and chemistry, would not decide to delist easily.

In addition, companies in high-tech industries experience greater uncertainty about their future business performance than those in other industries as well as a wider variety of risks, which should be shared with investors (Kim, 2012). The motivation to remain listed and keep up with the high costs for listing may be lower in non-high-tech industries than in high-tech industries. Thus, the following hypothesis is proposed.

Hypothesis 4. Firms in non-high-tech industries are more likely to delist voluntarily than firms in high-tech industries.

\section{RESEARCH MODEL AND SAMPLE SELECTION}

\section{Research Model}

This section investigates the attributes of voluntarily delisting firms. These firms were compared with firms that remained listed throughout the sample period to identify any differences. The attribute variables chosen were the shareholding ratio of the largest shareholder (LARGE), growth prospects (PERDM), liquidity (CASSET), and hightech industry (HTIDM).

According to Korean listing regulations, the shareholding ratio of the largest shareholder (LARGE) must exceed 95\% if a company wishes to delist voluntarily. Firms that fall short of this ratio must proceed with a tender offer if they wish to delist. The decision to delist voluntarily is easier when the shareholding ratio of the largest shareholder is already high, because there are fewer shares to be acquired.

The price to earnings ratio (PER; price per share/earnings per share) indicates how much of a company's profitability is reflected in the share price (i.e., company value). If the PER is relatively high, the company could be overvalued. Previous studies have mostly used the PER as a proxy for growth (Core et al., 1999; Park et al., 2006); however, in this research, the PER was used as a dummy variable because the industry PER varied widely during the 16-year sample period and needed to be controlled for. With reference to Kim (2012), this research also used a dummy variable. Thus, if a company's PER exceeded the relevant industry PER, the variable was assigned a value of one and zero otherwise. $^{7}$

Previous studies suggest that having sufficient free cash flow can be a reason for voluntary delisting (Jenson, 1986; Lehn and Poulsen, 1989). Firms that have large free cash flow due to good performance can more easily choose to go private. From the company's perspective, having a large amount of current assets is similar to having cash because such assets can be converted quickly. Accordingly, firms with high liquidity (CASSET) are more likely to delist voluntarily. 
In addition, non-high-tech firms have less motivation to stay listed than high-tech firms, because the former have lower demand for capital. Thus, because non-high-tech firms are more likely to delist voluntarily, a firm's inclusion in a high-tech industry (HTIDM) produces a negative relationship. The following model was formulated with delisting as the dependent variable and the four attribute variables as the variables of interest.

To empirically test the hypotheses, we estimate the following logistic regression model:

$$
\begin{aligned}
& D_{E L I S T} T_{i, t+1}=\alpha+\beta_{1} \text { PERDM }_{i, t}+\beta_{2} \text { LARGE }_{i, t}+\beta_{3} \text { CASSET }_{i, t}+\beta_{4} \text { HTIDM }_{i, t}+\beta_{5} L E V_{i, t}+\beta_{6} T_{A T} T_{i, t}+\beta_{7} R O A_{i, t} \\
& +\beta_{8} \operatorname{SIZE}_{i, t}+\varepsilon_{i, t}
\end{aligned}
$$

where $D E L I S T_{i, t+l}$ is a dummy variable equal to one if firm $i$ voluntarily delisted in period $t+1$ and zero otherwise; $P E R D M_{i}$ is a dummy variable equal to one if the PER of a firm was higher than the PER of the industry median in period $t$ and zero otherwise; $\mathrm{LARGE}_{i, t}$ is the shareholding ratio of the largest shareholder; $\operatorname{CASSET}_{i, t}$ is the current ratio (i.e., current assets/current debt); and $H T I D M_{i, t}$ is a dummy variable equal to one if firm $i$ belonged to a high-tech industry in period $t$ and zero otherwise.

This research used the following control variables taken from the literature: leverage (LEV), total asset turnover (TAT), return on assets (ROA), and company size (SIZE). LEV is a key indicator of financial solvency. Much of the literature has focused on the effects of leverage in private and public firms. Rao et al. (1995) found no statistically significant difference in leverage between public and private firms. However, when Halpern et al. (1999) classified firms that went private into two groups based on whether their largest shareholder ratios were high or low, they found that the group with higher ratios used significantly more leverage. In other words, firms with high leverage are more likely to voluntarily delist, resulting in a positive relationship.

TAT is a proxy for activity that indicates how efficiently a company uses its assets; a company with high TAT is more likely to voluntarily delist. ROA is calculated as the ratio of net income to assets. Because net income is the bottom line figure, it accurately reflects a company's profitability. Firms with high ROA are more inclined to go private to take full advantage of profits. Finally, as an adjustment for differences in company size, SIZE was included as the $\log$ of total assets in year $t$ (Kang et al., 2013).

\section{Sample Selection}

The subjects of this study were companies that voluntarily delisted from the Korean stock market between 1996 and 2012. The 49 companies applied for voluntary delisting from the KOSPI and KOSDAQ during this period. Listing status data were obtained from the Korea Exchange listing announcement system (http://www.krx.co.kr). Share price and financial data were obtained from KIS-Value and Korea's Corporate Filings Data Analysis, Retrieval, and Transfer system (http://dart.fss.or.kr).

Table 1 shows the sample selection process. Of the 49 firms that voluntarily delisted between 1996 and 2002, 34 were chosen after a filtering process. Of the 15 exclusions, seven financial institutions were excluded because they had used a different accounting approach, which compromised their comparability with nonfinancial institutions. Hankuk Fiber Co., Ltd was listed on the KOSDAQ Exchange on July 1, 1996, and delisted less than a year later on November 12, 1996. Because annual financial data were used in this research, Hankuk Fiber Co., Ltd was thus excluded. Three firms with unclear industry classifications and four without obtainable financial data were also excluded.

After the filtering process, 34 firms and 65 firm-years of financial data were selected. For three firms - Dongbang Sound, Daelim Metal Industries, and Danup Industries - financial data were usable only for the year preceding delisting. Consequently, the sample data include 34 samples of financial data for the ultimate year preceding delisting and 31 samples of financial data for the penultimate year before delisting. In total, 65 samples of annual financial data were used. 
Table 1. Sample selection of voluntarily delisted firms

\begin{tabular}{|c|c|c|}
\hline Sample selection & Firms & Firm-years \\
\hline Voluntarily delisted firms from 1996 to 2012 & 49 & 95 \\
\hline \multicolumn{3}{|l|}{ Exclusions } \\
\hline 1. Firms in the finance industry & $(7)$ & (14) \\
\hline 2. Firms without a necessary industry code & (3) & $(6)$ \\
\hline 3. Firms without necessary financial data & $(5)$ & $(10)$ \\
\hline Final samples & 34 & 65 \\
\hline
\end{tabular}

Notes: We considered 49 firms that voluntarily delisted from the KOSPI and KOSDAQ Exchanges between January 1, 1996 and December 31, 2012. Our sample contained 95 observations from the Korea Exchange, the KIS Value Database, and the Dart System of the Financial Supervisory Service. In the sample selection procedure, we excluded (1) firms in the finance industry, (2) firms without a necessary industry code, and (3) firms without financial data. After the selection procedure, we used a final sample of 65 firm-years for the analysis. Therefore, the full sample consisted of 34 samples of financial data for the year preceding delisting and 31 samples of financial data for the penultimate year before delisting.

The attributes of voluntarily delisted firms were investigated through a comparison of these firms with listed firms. The control sample comprises firms that remained listed in the year that a voluntarily delisted company delisted.

\section{EMPIRICAL ANALYSIS AND RESULTS}

\section{Descriptive Statistics, Univariate Analysis, and Correlation Analysis}

T-test and Wilcoxon-test analyses were conducted on voluntarily delisted and listed firms to investigate the significant differences in the key variables during the penultimate and ultimate years before delisting. The results are shown in Table 2.

Table 2. Descriptive statistics of the major variables

\begin{tabular}{|c|c|c|c|c|c|c|}
\hline \multirow[b]{2}{*}{ Variable } & \multicolumn{2}{|c|}{ Mean } & \multirow[b]{2}{*}{ t-value } & \multicolumn{2}{|c|}{ Median } & \multirow[b]{2}{*}{ z-valu } \\
\hline & $\begin{array}{c}\text { Voluntarily } \\
\text { delisted }\end{array}$ & Listed & & $\begin{array}{c}\text { Voluntarily } \\
\text { delisted }\end{array}$ & Listed & \\
\hline \multicolumn{7}{|c|}{ Panel A. Two years before sample firm voluntary delisting: $\mathrm{n}($ V.Delisted $)=31, \mathrm{n}($ Listed $)=592$} \\
\hline PERDM & 0.581 & 0.500 & 0.87 & 1.000 & 0.500 & 0.87 \\
\hline LARGE & 0.417 & 0.264 & $4.36^{* * *}$ & 0.407 & 0.241 & $3.88^{* * *}$ \\
\hline CASSET & 0.510 & 0.468 & 1.29 & 0.518 & 0.470 & $1.29^{*}$ \\
\hline HTIDM & 0.387 & 0.588 & $-2.21^{* *}$ & 0.000 & 1.000 & $-2.20^{* *}$ \\
\hline LEV & 0.502 & 0.473 & 0.61 & 0.477 & 0.461 & 0.56 \\
\hline TAT & 0.993 & 0.955 & 0.37 & 0.877 & 0.853 & 0.19 \\
\hline ROA & 0.008 & 0.016 & -0.37 & 0.027 & 0.030 & -0.17 \\
\hline SIZE & 25.225 & 25.391 & -0.66 & 25.313 & 25.096 & 0.92 \\
\hline
\end{tabular}

\begin{tabular}{l|c|c|c|c|c|c|c} 
Panel B. One year before sample firm voluntary delisting: $\mathrm{n}($ V.Delisted $)=34, \mathrm{n}($ Listed $)=608$ \\
\hline PERDM & 0.765 & 0.500 & $3.02^{* * *}$ & 1.000 & 0.500 & $3.00^{* * *}$ \\
\hline LARGE & 0.542 & 0.273 & $10.04^{* * *}$ & 0.494 & 0.246 & $4.58^{* * *}$ \\
\hline CASSET & 0.525 & 0.456 & $2.21^{* *}$ & 0.524 & 0.453 & $2.47^{* * *}$ \\
\hline HTIDM & 0.412 & 0.582 & $-1.96^{*}$ & 0.000 & 1.000 & $-1.95^{* *}$ \\
\hline LEV & 0.510 & 0.482 & 0.59 & 0.528 & 0.475 & 0.35 \\
\hline TAT & 1.056 & 0.975 & 0.62 & 0.892 & 0.890 & 0.00 \\
\hline ROA & 0.046 & -0.001 & $2.27^{* *}$ & 0.025 & 0.030 & -0.35 \\
\hline SIZE & 25.078 & 25.430 & -1.46 & 25.260 & 25.149 & 0.70 \\
\hline
\end{tabular}

Notes: Variable definitions and measurements are provided in Appendix. $* * *, * *$, and * denote significance at the $1 \%$, $5 \%$, and $10 \%$ levels, respectively.

For the growth variable (PERDM), the averages for voluntarily delisted and listed firms in the penultimate year are 0.581 and 0.500 , respectively. For the ultimate year, the averages are 0.765 and 0.500 , respectively. The average value of the growth variable is higher for voluntarily delisted firms, and there is a larger difference between the two types of firms in the ultimate year. The increase in the average value of PERDM suggests that the growth of voluntarily delisted firms improved compared with that of listed firms in the ultimate year. Thus, PERDM differs little between 
voluntarily delisted and listed firms in the penultimate year; however, a significant difference ( $1 \%$ level) emerges in the ultimate year.

The shareholding ratio of the largest shareholder (LARGE) is statistically significantly higher for voluntarily delisted companies than for listed firms in the penultimate and ultimate years before delisting. Specifically, in the penultimate year, LARGE is 0.417 for voluntarily delisted firms and 0.264 for listed firms. As firms preparing for voluntary delisting start acquiring shares, the differences in the shareholding ratio of the largest shareholders are even higher in the ultimate year when LARGE for voluntarily delisted firms is 0.542 , almost double its value for listed firms $(0.273){ }^{8}$ Thus, significant differences in LARGE at the $1 \%$ level are observed during the penultimate and ultimate years before delisting.

The liquidity variable (CASSET) is higher for voluntarily delisted firms during the penultimate and ultimate years, at 0.510 versus 0.468 and 0.525 versus 0.456 , respectively. This shows that the liquidity of voluntarily delisted firms is superior to that of listed firms. The differences are significant at the 5\% and $1 \%$ significance levels, respectively, for the penultimate and ultimate years before delisting. The high-tech industry variable (HTIDM) is higher for listed firms than for voluntarily delisted firms, as stated in Hypothesis 4 . The high-tech industry variable values for voluntarily delisted versus listed firms in the penultimate and ultimate years are 0.387 versus 0.588 and 0.412 versus 0.582 , respectively.

Of the control variables - LEV, TAT, ROA, and SIZE - only ROA shows a positive relationship with voluntarily delisted firms in the penultimate year. This suggests that firms with higher profitability chose to delist voluntarily more often than firms with lower profitability.

I analyzed whether any meaningful correlations exist between the different variables and no significant correlations were found since all the correlation coefficients remained below 0.5 . Further, a regression analysis of the variance inflation factors (VIF) was also conducted to ensure that no multicollinearity existed between the independent variables and the VIF of the logit regression analysis showed that no multicollinearity existed between the independent variables (Table 3$).{ }^{9}$

\section{Attributes of Voluntarily Delisting Firms: Multivariate Logit Analysis}

The results of logistic regression analysis for voluntary delisting are given in Table 3 . The regression coefficients of PERDM (the variable that represents company growth prospects) are 1.042 (Wald $\left.\mathrm{X}^{2}=10.80\right)$ and $2.035\left(\right.$ Wald $\mathrm{X}^{2}=$ 13.86) for the total period and the ultimate year, respectively. Both coefficients show a positive relationship at the $1 \%$ significance level. However, there is no significant relationship in the penultimate year. Thus, firms with higher growth prospects are more likely to delist voluntarily, supporting Hypothesis 1.

Table 3. Logit regression results

\begin{tabular}{|c|c|c|c|c|c|c|}
\hline Variable & \multicolumn{2}{|c|}{$t-2$} & \multicolumn{2}{|c|}{$t-1$} & \multicolumn{2}{|c|}{ Total } \\
\hline Constant & -5.395 & $(1.47)$ & -2.566 & $(0.27)$ & -4.072 & $(1.56)$ \\
\hline PERDM & 0.497 & $(1.34)$ & 2.035 & $(13.86)^{* * *}$ & 1.042 & $(10.80)^{* * *}$ \\
\hline LARGE & 4.716 & $(22.27)^{* * *}$ & 7.720 & $(47.77)^{* * *}$ & 5.868 & $(70.92)^{* * *}$ \\
\hline CASSET & 1.359 & $(1.41)$ & 2.141 & $(3.20)^{*}$ & 1.595 & $(3.95)^{* *}$ \\
\hline HTIDM & -0.824 & $(4.00)^{* *}$ & -0.558 & (1.67) & -0.702 & $(5.71)^{* *}$ \\
\hline LEV & -0.025 & $(0.00)$ & 1.552 & $(3.05)^{*}$ & 0.712 & $(1.36)$ \\
\hline TAT & -0.176 & $(0.21)$ & -0.574 & $(2.00)$ & -0.336 & $(1.60)$ \\
\hline ROA & -1.723 & $(1.16)$ & 0.161 & $(0.01)$ & -0.222 & $(0.11)$ \\
\hline SIZE & 0.023 & $(0.02)$ & -0.224 & $(1.48)$ & -0.080 & $(0.43)$ \\
\hline Concordant & \multicolumn{2}{|c|}{$76.2 \%$} & \multicolumn{2}{|c|}{$88.8 \%$} & \multicolumn{2}{|c|}{$81.8 \%$} \\
\hline Chi-square & \multicolumn{2}{|c|}{$38.87^{* * *}$} & \multicolumn{2}{|c|}{$101.78^{* * *}$} & \multicolumn{2}{|c|}{$133.04^{* * *}$} \\
\hline VIF value & \multicolumn{2}{|c|}{1.36} & \multicolumn{2}{|c|}{1.29} & \multicolumn{2}{|c|}{1.31} \\
\hline $\mathrm{N}$ & \multicolumn{2}{|c|}{623} & \multicolumn{2}{|c|}{642} & \multicolumn{2}{|c|}{1,265} \\
\hline
\end{tabular}

Notes: The table presents coefficients and Z-statistics (in parentheses). (t-2) is two years before a sample firm's voluntary delisting and (t-1) is one year before a sample firm's voluntary delisting. Based on the results by year, the concordance for year $t-2$ was $76.2 \%$ and the concordance for year $t-1$ was $88.8 \%$. Variable definitions and measurements are provided in Appendix. ${ }^{* *}, * *$, and $*$ denote significance at the $1 \%, 5 \%$, and $10 \%$ levels, respectively. 
The regression coefficient for the shareholding ratio of the largest shareholder (LARGE) is 4.716 (Wald $\mathrm{X}^{2}=70.92$ ), indicating a positive relationship at the $1 \%$ significance level. Furthermore, the regression coefficients for the penultimate and ultimate years before delisting show positive relationships at the $1 \%$ significance level, at 7.720 (Wald $\mathrm{X}^{2}=44.77$ ) and 5.868 (Wald $\mathrm{X}^{2}=22.27$ ), respectively. Thus, firms with high largest shareholder ratios are more likely to voluntarily delist, supporting Hypothesis 2 . The results also show that the forecast value of the shareholding ratio of the largest shareholder for voluntary delisting is more significant in the ultimate year than in the penultimate year.

The liquidity variable, CASSET, shows a strong relationship in the same direction as predicted at the 5\% and $10 \%$ significance levels for the total period and the ultimate year, respectively, supporting Hypothesis 3 . However, as with PERDM, there is no significant relationship in the penultimate year.

The high-tech industry variable (HTIDM) shows a strong relationship in the same direction as predicted at the 5\% significance level for both the total period and the penultimate year. The actual incidences of voluntary delisting show that non-high-tech firms in the textiles, clothing, construction, and wholesale/retail sectors voluntarily delisted more often than R\&D-intensive high-tech firms. This result suggests that the shape of Korea's industrial base has a greater influence on companies' decisions to delist voluntarily than do the commonly mentioned reasons for voluntary delisting such as control of corporate strategy and technical secrets.

\section{Changes to Voluntarily Delisted Firms After Delisting}

This analysis has thus far indicated that firms in non-high-tech sectors with greater largest shareholder ratios, growth prospects, and liquidity are more likely to delist voluntarily. This section analyzes how firms change after voluntarily delisting by investigating sample firms that chose to release financial data publicly after voluntarily delisting. Voluntarily delisted firms are then compared and contrasted with listed firms in the same industry. The control sample is chosen using the year of voluntary delisting as the base year; listed firms are selected if they remained listed five years after the base year.

Firms with financial data available for the years since their voluntary delisting can be categorized by their annual postdelisting periods: financial data are available for 28 firms for the first year after their voluntary delisting, 24 for the second year, 21 for the third year, 24 for the fourth year, and 19 for the fifth year. The control sample contains 421 listed firms in the first year, 341 in the second year, 307 in the third year, and 242 in both the fourth and fifth years.

Data available post-delisting - total assets, revenue, and net income - are used for comparisons of management performance. The results are shown in Table 4. Figure 1 shows the performance ratios of voluntarily delisted firms to listed firms during the five years after delisting. A firm's performance is measured based on total assets, sales, and net income.

Panel A of Table 4 shows that the average total assets of voluntarily delisted firms after their delisting are lower than those of listed firms. For all five years after delisting, voluntarily delisted firms continue to grow at a lower rate relative to listed firms, from $26.2 \%$ (KRW 107,000 million for voluntarily delisted firms versus KRW 408,300 million for listed firms) to $16.4 \%(143,200$ versus 870,800$)$. This finding suggests that the average total assets of voluntarily delisted firms relative to listed firms decrease after delisting and become smaller over time. ${ }^{10}$

Regarding revenue, the average sales for voluntarily delisted firms in the first year after delisting was compared with that of listed firms and which are KRW 101,900 million and KRW 365,200 million respectively. Thus, the revenue of voluntarily delisted firms is $27.9 \%$ that of listed firms. In the fifth year after delisting, average sales are KRW 115,100 million for voluntarily delisted firms and KRW 807,600 million for listed firms, a ratio of $14.3 \%$. This finding suggests that revenue growth among voluntarily delisted firms decreases each year.

Furthermore, net income growth shows a decreasing trend after companies delist. In the first year after delisting, voluntarily delisted firms have the average net income of KRW 3,759 million, while the average net income for listed firms is KRW 16,780 million. In the fifth year, the net incomes are KRW 6,968 million and KRW 58,210 million, respectively. Hence, the ratio decreases from $22.4 \%$ to $12.0 \%$, showing a widening gap in the net income growth rate. 
Meanwhile, we can also identify the difference between the two groups in Panel B of Table 4 based on the change in performances of each group for the voluntary delisted firms and the listed firms over the five periods ( Panel B of Table 4).

Table 4. Performance after voluntary delisting

\begin{tabular}{|c|c|c|c|}
\hline \multicolumn{3}{|l|}{ Panel A: Performance Ratio } & Unit: KRW 1 million \\
\hline Variable & Voluntarily delisted & Listed & $\begin{array}{c}\text { Performance ratio } \\
\text { (Voluntarily delisted / Listed) }\end{array}$ \\
\hline \multicolumn{4}{|c|}{ the first year( $(+1)$ after sample firm voluntary delisting } \\
\hline $\mathbf{N}$ & 28 & 411 & \\
\hline Average Assets & 107,000 & 408,300 & $26.2 \%$ \\
\hline Average Sales & 101,900 & 365,200 & $27.9 \%$ \\
\hline Average Net Income & 3,759 & 16,780 & $22.4 \%$ \\
\hline \multicolumn{4}{|c|}{ the second year( $(t+2)$ after sample firm voluntary delisting } \\
\hline $\mathbf{N}$ & 24 & 341 & \\
\hline Average Assets & 92,710 & 504,500 & $18.4 \%$ \\
\hline Average Sales & 80,800 & 461,700 & $17.5 \%$ \\
\hline Average Net Income & 2,137 & 25,030 & $8.5 \%$ \\
\hline \multicolumn{4}{|c|}{ the third year $(t+3)$ after sample firm voluntary delisting } \\
\hline $\mathbf{N}$ & 21 & 307 & \\
\hline Average Assets & 107,200 & 560,100 & $19.1 \%$ \\
\hline Average Sales & 101,500 & 547,600 & $18.5 \%$ \\
\hline Average Net Income & 3,512 & 37,120 & $9.5 \%$ \\
\hline \multicolumn{4}{|c|}{ the fourth year $(t+4)$ after sample firm voluntary delisting } \\
\hline $\mathbf{N}$ & 19 & 242 & \\
\hline Average Assets & 115,100 & 761,000 & $15.1 \%$ \\
\hline Average Sales & 114,300 & 725,600 & $15.8 \%$ \\
\hline Average Net Income & 1,764 & 57,060 & $3.1 \%$ \\
\hline \multicolumn{4}{|c|}{ the fifth year(t+5) after sample firm voluntary delisting } \\
\hline $\mathbf{N}$ & 19 & 242 & \\
\hline Average Assets & 143,200 & 870,800 & $16.4 \%$ \\
\hline Average Sales & 115,100 & 807,600 & $14.3 \%$ \\
\hline Average Net Income & 6,968 & 58,210 & $12.0 \%$ \\
\hline
\end{tabular}

(Panel 4, Table B continued on next page) 
(Table 4, Panel B continued)

Panel B: Performance Change

\begin{tabular}{|c|c|c|c|c|c|c|}
\hline \multicolumn{2}{|c|}{ After sample firm voluntary delisting } & $t+1$ & $\mathbf{t}+2$ & $\mathbf{t}+3$ & $t+4$ & $\mathbf{t}+5$ \\
\hline \multirow{7}{*}{$\begin{array}{l}\text { Voluntarily } \\
\text { delisted }\end{array}$} & $\mathbf{N}$ & 28 & 24 & 21 & 19 & 19 \\
\hline & Average Assets & 107,00 & 92,710 & 107,200 & 115,100 & 143,200 \\
\hline & $\begin{array}{l}\text { Performance } \\
\text { change(Assetst }+1 / \text { Assetst })\end{array}$ & $86.6 \%$ & $115.6 \%$ & $107.4 \%$ & $124.4 \%$ & $86.6 \%$ \\
\hline & Average Sales & 101,900 & 80,800 & 101,500 & 114,300 & 115,100 \\
\hline & $\begin{array}{l}\text { Performance ratio } \\
\text { (Salest }+1 / \text { Salest })\end{array}$ & $79.3 \%$ & $125.6 \%$ & $112.6 \%$ & $100.7 \%$ & $79.3 \%$ \\
\hline & Average Net Income & 3,759 & 2,137 & 3,512 & 1,764 & 6,968 \\
\hline & $\begin{array}{l}\text { Performance ratio } \\
(\mathrm{NIt}+1 / \mathrm{NIt})\end{array}$ & $56.9 \%$ & $164.3 \%$ & $50.2 \%$ & $395.0 \%$ & $56.9 \%$ \\
\hline \multirow{7}{*}{ Listed } & $\mathbf{N}$ & 411 & 341 & 307 & 242 & 242 \\
\hline & Average Assets & 408,300 & 504,500 & 560,100 & 761,000 & 870,800 \\
\hline & $\begin{array}{l}\text { Performance } \\
\text { ratio(Assetst+1/Assetst) }\end{array}$ & $123.6 \%$ & $111.0 \%$ & $135.9 \%$ & $114.4 \%$ & $123.6 \%$ \\
\hline & Average Sales & 365,200 & 461,700 & 547,600 & 725,600 & 807,600 \\
\hline & $\begin{array}{l}\text { Performance } \\
\text { ratio(Salest }+1 / \text { Salest })\end{array}$ & $126.4 \%$ & $118.6 \%$ & $132.5 \%$ & $111.3 \%$ & $126.4 \%$ \\
\hline & Average Net Income & 16,780 & 25,030 & 37,120 & 57,060 & 58,210 \\
\hline & $\begin{array}{l}\text { Performance } \\
\text { ratio(NIt+1/NIt) }\end{array}$ & $149.2 \%$ & $148.3 \%$ & $153.7 \%$ & $102.0 \%$ & $149.2 \%$ \\
\hline
\end{tabular}

Figure 1. Performance Ratios of Voluntarily Delisted Firms to Listed Firms after Delisting.

Performance ratio

(Volun. delisting/Listing)

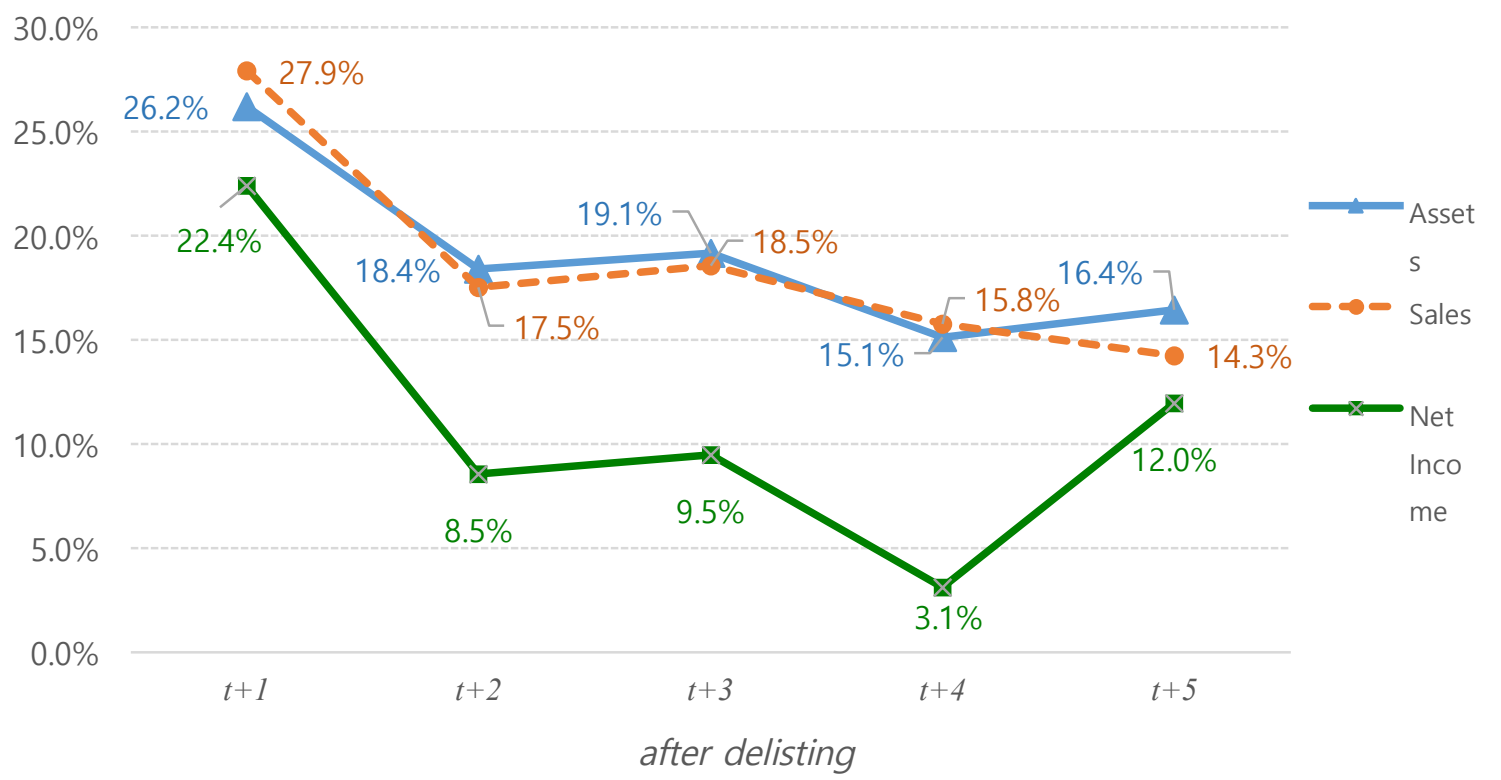

Notes: Firm performance is measured by total assets, sales, and net income. 
The average of total assets, sales, and net income of the voluntarily delisted firms in the second year were decreased by $86.6 \%, 79.3 \%$, and $56.9 \%$ respectively, compared with the first year. On the other hand, The average of total assets, sales, and net income of the listing firms increased by $123.6 \%, 126.4 \%$, and $149.2 \%$ respectively in the same periods.

However, we should note that performance variables of the voluntarily delisted firms have relevantly larger fluctuations than that of the listing firms.

The average total assets for voluntarily delisted firms in the first year after delisting are KRW 107,000 million and the fifth year's average assets of delisted firms are KRW 143,200 million. This means that the average total assets of the voluntary delisted firms increased by approximately 1.34 times $(143,200$ divided by 107,000$)$ after five years since delisting. However, the rate of increase of the listed firms' average assets is approximately 2.13 times $(870,800$ divided by 365,200$)$ during the same periods.

And the average sales and the average net income of voluntary delisted companies were increased by approximately 1.13 times $(115,100$ divided by 101,900) and 2.21 times $(6,968$ divided by 3,759) respectively. But the average sales and the average net income of listed firms were increased by approximately 1.85 times $(807,600$ divided by 365,200$)$ and 3.47 times $(58,210$ divided by 16,780) during the same period. In this comparison, we can note that all the performance variables for the listed firms had larger increase.

The results in Table 4 regarding post-delisting management performance differ from the firm's expectations. Although the analysis is limited to five years, the results raise questions about whether management decisions about voluntary delisting are appropriate. Thus, any listed firm considering voluntarily delisting should exercise caution.

\section{CONCLUSIONS}

Although the number of voluntarily delisting firms increased steadily between 1996 and 2012, empirical research on this topic has been limited by difficulties in data collection. This research examined the attributes of voluntarily delisted firms by focusing on factors such as growth prospects, largest shareholder ratio, liquidity, and industry sector. In addition, voluntarily delisted firms were compared with listed firms within the same industry to assess changes in management performance after voluntary delisting. Firms that voluntarily delisted from the KOSPI and KOSDAQ Exchanges between 1996 and 2012 were used for the analysis. Research models were built for the four presented hypotheses and empirical analyses were conducted through logistic regression.

The results of the research are as follows. First, firms with higher growth voluntarily delist more frequently. The undervaluation of firm value is often cited as a major reason for voluntary delisting. If a firm is valued below the figure its management believes to be the intrinsic value, management may choose to voluntarily delist. In addition, firms with high growth prospects voluntarily delist to enable the largest shareholders to take full advantage of future growth value.

Second, firms with high largest shareholder ratios voluntarily delist more frequently than those with low largest shareholder ratios, which could be interpreted in two ways. Firms with high largest shareholder ratios are in a better position to acquire the minimum shareholder ratio required under the regulations to apply for voluntary delisting. Because it is less costly for such firms to acquire any remaining shares, it is easier for them to privatize. Another perspective accounts for the influence of the compulsory delisting regulations. Listed firms are required to meet certain minimum trading volumes for their shares each month. If those requirements are not met, the companies are forced to delist. As the shareholding ratio of the largest shareholder increases, the number of shares being traded in the stock market decreases. Minimum trading volumes might not be met because of the low number of outstanding shares. Moreover, in such cases, firms have less need to remain listed because they have less incentive to raise capital through stock markets. Consequently, firms with high largest shareholder ratios have more incentive than other firms to voluntarily delist. This is the key incentive for Korean firms to voluntarily delist.

Third, firms with higher liquidity more frequently delist voluntarily compared with firms with lower liquidity. Because the voluntary delisting process requires significant capital, firms must have sufficient available liquidity. The results of this analysis revealed that voluntarily delisted firms had higher liquidity than listed firms within the same industry. 
Fourth, firms in non-high-tech industries more frequently voluntarily delist than those in high-tech industries. In Korea, firms in non-high-tech industries such as textiles, clothing, construction, and wholesale/retail more often voluntarily delist than high-tech firms concerned about management secrets and technology leaks.

Additionally, in the analysis of changes in firms after voluntary delisting and the comparison of such firms with continuously listed companies, it was found that total assets, sales, and net profit decreased over time for companies that delisted. This result suggests that the largest stockholders or executives in such companies should more prudently consider the decision to voluntarily delist.

In this study, a specific empirical analysis of the characteristics of voluntarily delisted firms was conducted, and a contribution was made to this field by identifying changes in the business performance of companies after their voluntary delisting. Of the 35 firms that voluntarily delisted from the KOSDAQ, 22 (63\%) went private within five years, possibly because their managers lacked an understanding of the listing or because the market participants and managers had different perspectives. The results of this study indicated that it is necessary to provide firms considering listing with sufficient guidance. This study is thus meaningful because it presents useful information for the decisionmaking of companies considering applying for voluntary delisting, including changes in the business performance indicators of voluntarily delisted firms before and after their delisting.

\section{AUTHOR BIOGRAPHY}

Sun-Min Kang is an associate professor of accounting in the College of Business Administration at Chung-Ang University. Her main research interests are accounting system and corporate governance. E-mail: skang@cau.ac.kr

\section{REFERENCES}

Carpentier, C., and J. M. Suret. (2010). Entrepreneurial Equity Financing and Securities Regulation: An Empirical Analysis. International Small Business Journal, 30(1) 41-64.

Chang, H., S. H. Suh, E. M. Werner, and J. Zhou. (2012). The Effect of SOX on the Predictability of Future Cash Flows in Litigious and Non-litigious Industries. Asia-Pacific Journal of Accounting \& Economics, 19(2) 210-226.

Chang, P. L., and W. L. Chen. (2002). The Effect of Human Resource Management Practices on Firm Performance: Empirical Evidence from High-tech Firms in Taiwan. International Journal of Management, 19(4) 622-631.

Chatterjee, S., and B. Price. (1977). Regression Analysis by Example. New York: John Wiley \& Sons.

Core, J. E., W. H. Robert, and D. F. Larcker. (1999). Corporate Governance, Chief Executive Officer Compensation and Firm Performance. Journal of Financial Economics, 51(3) 371-406.

DeAngelo, H., L. DeAngelo, and E. Rice.(1984). Going Private: Minority Freeze-outs and Stockholder Wealth," Journal of Law and Economics, 27(2) 367-401.

Himmelberg, C. P., and B. C. Petersen. (1994). R\&D and Internal Finance: A Panel Study of Small Firms in High-Tech Industries. Review of Economics and Statistics, 76(1) 38-51.

Halpern, P., R. Kieschnick, and W. Rotenberg. (1999). On the Heterogeneity of Leveraged Going Private Transactions. Review of Financial Studies, 12(2) 281-309.

Hwang, I. T., S. M. Kang, and S. J. Jin. (2014). A Delisting Prediction Model based on Nonfinancial Information. Asia-Pacific Journal of Accounting \& Economics 21(3) 328-347.

Jensen, M. C. (1986). Agency Costs of Free Cash Flow, Corporate Finance, and Takeovers. American Economic Review, 76(2) 323-329.

Jeong, J. H., and J. B. Ha. (2006). The Effect of Tender-offer on the Value of the Firm in Korea. Korean Journal of Financial Management, 23(1) 1-47.

Kang, S. M., I. T. Hwang., and S. J. Jin. (2013). The BIS Capital Ratio and the Debt Ratio: The Failure Prediction Model for Mutual Savings Banks. Korean Management Review, 42(1) 1-28.

Kim, C. S., and D. Cho. (1996). A Research on the Determinants of Liquidity Investment in Korea. Asian Review of Financial Research, 9(2) 187-209.

Kim, S. J. (2012). The Effect of the Future R\&D Investment Induced by Managers' Cash Compensation Incentive on the Future Firm Performance. Korean Accounting Journal, 21(4) 1-37.

KOSDAQ Listed Companies Association. (2010). The Analysis of KOSDAQ Delisted Companies' Insolvent Pattern and Process. Seoul: KOSDAQCA Research Paper.

KOSPI/KOSDAQ Market Listing Regulations. (2014). Retrieved from http://global.krx.co.kr/contents/GLB/06/0601/0601000000/GLB0601000000.jsp\#

Lehn, K., and A. Poulsen. (1989). Free Cash Flow and Stockholder Gains in Going Private Transactions. The Journal of Finance, 
44(3) 771-787.

Leuz, C., A. Triantis, and T. Y. Wang. (2008). Why do Firms go Private? Causes and Economic Consequences of Voluntary SEC Deregistrations. Journal of Accounting and Economics, 45(2-3) 181-208.

Marosi, A., and N. Massoud. (2007). Why do Firms go Private?. Journal of Financial and Quantitative Analysis, 42(2) $421-442$.

Morgenstern, M., P. Nealis, and K. Kleinman. (2004). Going Private: A Reasoned Response to Sarbanes-Oxley. 3rd Annual Government-Business Forum on Small Business Capital Formation. Washington, DC.

Park, A. Y., K T. Lee, and S. C. Lee. (2006). The Effect of Executive Stock Options Compensation and Ownership Structure on R\&D Investment. Korean Accounting Review, 31(2) 89-126.

Park, H. J., and H. M. Jee. (2010). The Effect of Substantial Investigation System of Delisting on Reliability of Accounting Information. Taxation and Accounting Journal, 11(4) 253-274.

Pour, K. E., and M. Lasfer. (2013). Why do Companies Delist Voluntarily from the Stock Market?. Journal of Banking \& Finance, 37 4850-4860.

Rao, S. M., M. S. Waters, and B. Payne. (1995). Going Private: A Financial Profile. Journal of Financial and Strategic Decisions 8(3) 53-59.

United States House of Representatives. The Sarbanes-Oxley Act of 2002. Public Law 107-204 [H. R. 3763]. Washington, DC: Government Printing Office. 


\section{END NOTES}

1. In 2004, eBay, the largest shareholder of Auction Co., Ltd, bought a sizeable share through an open-market purchase, thus meeting the requirements of the stock exchange, and voluntarily delisted Auction Co., Ltd. Additionally, Chinese Food Packaging, a KOSDAQ-listed company, decided to voluntarily delist via an openmarket purchase in 2009, as did Kookje Electric Korea, an affiliate of Hitachi Kokusai Electric Inc., in 2014. Additionally, in 2015, Kyung Chang Industrial Corporation announced that it would make a public purchase of the registered common stock of its affiliate, $\mathrm{KCW}$. A company representative explained, "This public purchase aims to found a joint company, and if it meets the required procedures of the relevant laws, regulations and rules after the purchase, we will apply for the voluntary delisting of $\mathrm{KCW}$ under the cooperation of the largest stockholder."

2. Songwon Color listed on the KOSPI Exchange on January 30, 1996 and delisted on December 5, 2001. Seah Metal listed on the KOSDAQ Exchange on May 10, 2001 and delisted on December 20, 2004. These two firms went private again only three to five financial years after going public. T-Broad listed on the KOSDAQ Exchange on July 26, 2011, but delisted on November 1, 2011.

3. Dell World 2013: The Very Public Resurgence of a Newly-Private Company. Retrieved from http://www.alleywatch.com/2013/12/dell-world-2013-the-very-public-resurgence-of-a-newly-private-company/

4. Listing periods are categorized based on monthly units. For example, EDIS Medical Co., Ltd was listed on the KOSDAQ on January 24, 2003 and delisted on June 29, 2010. Since the company was listed for seven years and five months, it was classified as being listed for "less than eight years." Sungwoo Mold Co., Ltd, which was listed on August 21, 2001 and delisted on April 21, 2010, was categorized as being listed for "less than nine years," because the listing period was eight years and eight months in total.

5. The foreign literature on voluntary delisting uses free cash flow instead of liquidity (Jenson, 1986; Lehn and Poulsen, 1989). However, this research uses liquidity as a proxy for a company's ability to make public tender offerings.

6. Himmelberg and Petersen (1994) classified chemicals and drugs, machinery, electrical equipment, communications, and instruments with a high R\&D to sales ratio as high-tech industries. Chang and Chen (2002) classified integrated circuits, computers, peripherals, telecommunications, optical electronics, precision machinery, and biotechnology as high-tech industries. A similar set of industries was identified by Himmelberg and Petersen (1994), Chang and Chen (2002), and Kim (2012).

7. Kim (2012) assigned a value of 1 to a company if the ratio of the market value to the book value per share was higher than the median, and a value of 0 otherwise, as a proxy variable of companies' growth, to analyze the relationship between manager compensation and investment in R\&D costs in companies with high growth. This study also uses the PER as a dummy variable to examine whether the value of companies that voluntarily delist are over- or underestimated in the same industry.

8. Most voluntarily delisted firms have high largest shareholder ratios before delisting. However, for eight firms, the largest shareholder changed during the two years before delisting. In eight other firms, institutional investors became the main shareholders within two years of delisting. It is thus likely that such new largest shareholder or institutional investor involvement was for voluntary delisting. However, the involvement of institutional investors was not considered in this research because of difficulties in gathering information about such involvement in continuously listed firms.

9. The VIF (variance inflation factor) is known to be more desirable than simple correlation coefficients for providing accurate information on multicollinearity among explanatory variables. Chatterjee and Price (1977) insisted that there is no serious problem of multicollinearity if the VIF is less than 10.

10. In the penultimate and ultimate years before delisting, no significant differences in SIZE are found between voluntarily delisted firms and listed firms, as shown in Table 4. However, the SIZE value is lower for voluntarily delisted firms at the $1 \%$ level for all five years after delisting. 


\section{APPENDIX}

Definition of Variables
\begin{tabular}{l|l} 
DELIST $_{i, t+1}$ & Coded as 1 if firm $i$ voluntarily delisted in period $t+1$ and 0 otherwise. \\
\hline PERDM $_{i, t}$ & $\begin{array}{l}\text { The PER dummy represents the growth of a firm. It was coded as } 1 \text { if the PER of a firm was higher } \\
\text { than the PER of the industry median in period } t \text { and } 0 \text { otherwise. The PER is the price to earnings } \\
\text { ratio (i.e., price per share/earnings per share). }\end{array}$ \\
\hline LARGE $_{i, t}$ & The shareholding ratio of the largest shareholder. \\
\hline CASSET $_{i, t}$ & Current ratio: current assets/current debt. \\
\hline HTIDM $_{i, t}$ & Coded as 1 if firm $i$ belonged to a high-tech industry in period $t$ and 0 otherwise. \\
\hline LEV $_{i, t}$ & Debt ratio: debt/assets. \\
\hline TAT $_{i, t}$ & Total asset turnover ratio: sales/assets. \\
\hline ROA $_{i, t}$ & Net income ratio: net income/assets. \\
\hline SIZE $_{i, t}$ & Firm size: log of total assets.
\end{tabular}




\section{NOTES}

